\title{
Developments
}

\section{To Allow or Refuse Entry: What Does the Law Demand in the Refugee Crisis at Europe's Internal State Borders?}

\author{
By Alexander Peukert, Christian Hillgruber, Ulrich Foerste, \& Holm Putzke*
}

\begin{abstract}
The following Article deals with the issue of whether the Federal Republic of Germany is responsible for examining the applications for international protection of third-country nationals who, since the start of the European refugee crisis have arrived at the German land border or, alternatively, whether Germany is obligated to refuse entry to such persons and relegate them to an adjacent transit country. In most cases, this would require Austria, in particular, to examine these applications for protection. The position outlined in this inquiry may be applied to all internal borders between European Union Member States.
\end{abstract}

\footnotetext{
* The authors are law professors at the universities of Frankfurt a.M., Bonn, Osnabrück, and Passau. The Article originally appeard in German. See Peukert et al., Einreisen lassen oder zurückweisen? Was gebietet das Recht in der Flüchtlingskrise an der deutschen Staatsgrenze?, 36 ZEITSCHRIFT FÜR AUSLÄNDERRECHT UND AUSLÄNDERPOLITIK (ZAR) 131-136 (2016).
} 


\section{A. Introduction}

The migration crisis is also a crisis of law. The fact that hundreds of thousands of migrants, since the summer of 2015, were capable of arriving in Germany via the Balkan route only became possible because many Member States of the European Union (EU) did not fulfill their external border obligations as per the Schengen Borders Code. ${ }^{1}$ Third-country nationals may only enter an EU Member State if they have a visa or if they apply for international protection precisely at that location, according to Article 13, paragraph 1 Dublin-III-REG. If arrivals neither have a visa, nor apply immediately for international protection, they are categorically to be turned away according to Article 13, paragraph 1 in conjunction with Article 5, paragraph 1 of the Schengen Borders Code. The combination of these laws means that the practice of "waving through" to the target state, such as Germany, is clearly illegal.

What is contentious, though, is whether the practices that the German Federal Government (Federal Government) has executed since September of 2015 to the time of this writing in February 2017 are compatible with EU law, namely: (a) reintroducing checks at the internal border to Austria, but at the same time (b) permitting the entry of all individuals to Germany who arrive at the border to Austria, and (c) providing protection to these third-state national applicants.

The legal situation is relatively unclear, due to the complex blend of European and German law, and because of the multitude of relevant provisions that have overriding-and sometimes contradictory-application. The result of the analysis is nevertheless unequivocal; the policy of open borders lacks a viable legal basis. As regards the right of asylum under Article 16a of the German Basic Law, this finding follows from the Basic Law itself, which explicitly states that the right of asylum "may not be invoked by a person who enters the federal territory from a member state of the European Communities or from another third state in which application of the Convention Relating to the Status of Refugees and of the Convention for the Protection of Human Rights and Fundamental Freedoms is assured." ${ }^{2}$ As will be explained in the following section, the EU asylum acquis also provides that persons applying for international protection ${ }^{3}$ ought to be refused entry at the German-

\footnotetext{
${ }^{1}$ Regulation 562/2006, of the European Parliament and the Council of 15 March 2006 Establishing a Community Code on the Rules Governing the Movement of Persons Across Borders (Schengen Borders Code), 2006 O.J. (L 105) 1, 1-32 [hereinafter Schengen Borders Code].

2 See Grundgesetz [GG] [BASIC LAW], art. 16a, para. 2, sentence 1, translation at http://www.gesetze-iminternet.de/englisch_gg/index.html; see also Asylgesetz [AslyG] [Asylum Act], Sept. 2, 2008, BundeSGESETZBLATT [BGBLI] at 1798, § 1, para. 1, no. 1-2, §13, para. 1-2, § 18, para. 2, no. 1, § 26a, para. 1, sentence 1 (Ger.).

${ }^{3}$ For this "second track" of the right of asylum, see Asylgesetz [AslyG] [Asylum Act], Sept. 2, 2008, BGBL. I at 1798, $\S \S 1$ para. 1, no. 2, 3, 4, 13 para. 1-2 (Ger.). See also Directive 2011/95, of the European Parliament and of the Council of 13 December 2011 on Standards for the Qualification of Third-Country Nationals or Stateless Persons as Beneficiaries of International Protection, for a Uniform Status for Refugees or for Persons Eligible for Subsidiary Protection, and for the Content of the Protection Granted, 2011 O.J. (L 337) 9, 14.
} 
Austrian border-or at other internal borders between Member States. Apparently, the Federal Government has also endorsed this position. ${ }^{4}$

\section{B. Article 20 Paragraph 4 Dublin-III-REG-Requirements and Legal Consequences}

Even though the Schengen and Dublin Systems have factually collapsed, they both are still legally valid. At least the German Federal Government as well as the European Commission assume so. ${ }^{5}$ For that reason, the Dublin-III-REG ${ }^{6}$ is used as the defining legal basis for the following legal assessment. This finding remains valid for the currently debated proposal for a recast of the Dublin-III-REG, because the proposed Dublin-IV-REG leaves the basic structure, the aims, and, in particular, the core provision for our argument-Article 20, paragraph 4 Dublin-III-REG - intact. ${ }^{7}$

First of all, pursuant to the Dublin-III-REG, the question concerning which Member State is objectively responsible for examining the application for granting international protection should be distinguished from the question of which Member State is responsible for starting the Dublin procedure in the first place, which logically precedes the former Dublin procedure, and the later substantive asylum procedure.

According to Article 3, paragraph 1 of the Dublin-III-REG:

Member States shall examine any application for international protection by a third-country national or a stateless person who applies on the territory of any one of them, including at the border or in the transit zones. The application shall be examined by a single Member State, which shall be the one which the criteria set out in Chapter III [Dublin-III-REG] indicate is responsible.

\footnotetext{
4 See Regierungsentwurf [Cabinet Draft], DEUTSCHER BUndeSTAGS: DruCKSACHEN [BT] 18/7311, http://dipbt.bundestag.de/dip21/btd/18/073/1807311.pdf (Ger.) (presenting a response of the federal government to a small inquiry) [hereinafter Response].

${ }^{5}$ See European Commission Press Release IP/16/585, The Commission, Back to Schengen: Commission Proposed a Complete Restoration of the Schengen System (Mar. 4, 2016), http://europa.eu/rapid/press-release_IP-16585_en.htm.

${ }^{6}$ See Regulation 604/2013, of the European Parliament and of the Council of 26 June 2013 Establishing the Criteria and Mechanisms for Determining the Member State Responsible for Examining an Application for International Protection Lodged in One of the Member States by a Third-Country National or a Stateless Person, 2013 O.J. (L 180) 31-59 [hereinafter Dublin-III-REG].

7 See Proposal for a Regulation Establishing the Criteria and Mechanisms for Determining the Member State Responsible for Examining an Application for International Protection Lodged in One of the Member States by a Third-Country National or a Stateless Person (recast), at art. 21, para. 4, COM (2016) 270 final (May 4, 2016). See also Dublin-III-REG, supra note 6, art. 20, para. 4.
} 
Pursuant to this, Germany may only be responsible in exceptional cases, namely when a close family relative of the applicant already has international protection status with permanent residence in Germany or has a current pending application for protection. ${ }^{8}$

In contrast, the logically preceding question on which Member State is responsible to start the Dublin procedure is determined based on Article 20 of the Dublin-III-REG. Under Article 20, paragraph 1 of the Dublin-III-REG, the process of determining the Member State responsible shall start as soon as an application for international protection is lodged with a Member State. An application can be lodged either with a German authority within Germany or with the border guards stationed at the border. In principle, the applicant would then have a right to residence while in the process of waiting for a decision to be made on which Member State is responsible for examining the application. ${ }^{9}$

Yet, there is a previously often overlooked, special provision that applies at EU internal borders; pursuant to the first sentence of Article 20, paragraph 4, subparagraph 1 of the Dublin-III-REG, the duty of conducting the Dublin procedure, and possibly a subsequent substantive asylum proceeding, lies with the state of arrival, for example Austria, and not with the state of destination, for example, Germany. The provision reads: "Where an application for international protection is lodged with the competent authorities of a Member State by an applicant who is on the territory of another Member State, the determination of the Member State responsible shall be made by the Member State in whose territory the applicant is present."

\section{The Provision's Scope of Application}

This provision, as its wording makes clear, sees the state of residence as responsible for asylum matters and applies not only in the case of an application submitted to embassies and consulates, but also in the case of an application for international protection made at the border to another Member State. This result is in line with the European legislature's intent. The Commission's explanatory proposal on Article 4, paragraph 4 (Section 5 in the proposal) of the Dublin-II-REG - which is the unaltered predecessor norm of Article 20, paragraph 4 of the Dublin-III-REG in that matter-states:

The procedure for determining the Member State responsible must be conducted by the Member State on whose territory the asylum seeker is, including where the applicant contacts the authorities of another

\footnotetext{
${ }^{8}$ See Dublin-III-REG, supra note 6, arts. 8-10.

${ }^{9}$ See Directive 2013/32 of the European Parliament and the Council of 26 June 2013 on Joint Procedures for Recognising and Denying International Protection, 2013 O.J. (L 180) 60, 60-95, art. 9, para. 1, sentence 1.
} 
Member State, e.g. at a diplomatic or consular post or at the frontier. The rule established in this paragraph makes it possible to assign the asylum application to the State whose competence is determined by the applicant's presence. ${ }^{10}$

The Commission's explanation is sensible, as transit-countries become disincentivized to tolerate or even support irregular secondary movements to other Member States.

With this procedural rule, the Dublin-III-REG maintains the principle "that the responsibility for examining an application should primarily lie with the Member State which played the greatest part in the applicant's entry into and residence in the territories of the Member States, with some exceptions designed to protect family unity". ${ }^{11}$ This reasoning applies not only to the state of initial entry, but also to "transit" Member States that permit and have even previously encouraged third-country nationals to enter their territory and continue their journey to the Member State of their choice. Yet, as is made clear in the Dublin and Schengen Systems, asylum seekers have no right to choose their Member State of destination because the Common European Asylum System is not an economic migration scheme. $^{12}$

Now, the responsibility of Austria as per Article 20, Paragraph 4 of Dublin-III-REG could not be put into practice as long as the German-Austrian border could be crossed without being

${ }^{10}$ Proposal for a Council Regulation Establishing the Criteria and Mechanisms for Determining the Member State Responsible for Examining an Asylum Application Lodged in One of the Member States by a Third-Country National, COM (2001) 447 final (July 26, 2001), http://eur-lex.europa.eu/legalcontent/EN/TXT/?uri=OJ:JOC_2001_304_E_0192_01 (proposing the regulation on the assumption that it does not contradict the genesis of Dublin-II-REG), with Roman Lehner, Grenze zu dank Art. 20 Abs. 4 Dublin-III-VO? Eine Replik, VERFASSUNGSBLOG (Feb. 26, 2016), http://verfassungsblog.de/grenze-zu-dank-art-20-abs-4-dublin-iii-vo-einereplik/. See Alexander Peukert, Christian Hillgruber, Ulrich Foerste, \& Holm Putzke, Nochmals: Die Politik offener Grenzen ist nicht rechtskonform, VERFASSUNGSBLOG (Mar. 2, 2016), http://verfassungsblog.de/nochmals-die-politikoffener-grenzen-ist-nicht-rechtskonform/. A contrary view of the legislative body of the Union is not documented to the extent that is evident. The Commission alone cannot reinterpret the Dublin System that was legislated on their request by the Council in 2003, and then by the Parliament in 2013.

${ }_{11}$ Proposal for a Regulation of the European Parliament and of the Council Establishing the Criteria and Mechanisms for Determining the Member State Responsible for Examining an Application for International Protection Lodged in One of the Member States by a Third-Country National or a Stateless Person (Recast), at 3, COM (2008) 820 final (Dec. 3, 2008); see also Dublin-III-REG (showing the increased efficiency of the modus operandi of the Dublin-IIREG).

12 Session of the European Council-Conclusion, EUCO 1/16, ST 12016 INIT (Feb. 18 and 19, 2016) 4. That also applies, whenever the entry into the European Union is made via a Member State such as Greece-where no return can be made due to the systemic shortfalls of the local asylum system. For the meaning of this circumstance of the responsibility, see Dublin-III-REG, supra note 6, art. 3, para. 2. For the criminal liability of the smuggling third-state nationals into such a Member State, see Bundesgerichtshof [BGH] [Federal Court of Justice] Feb. 26, 2015, NEUE JURISTISCHE WOCHENSCHRIFT [NJW] 2274. 
checked. Yet, since September 13, 2015, Germany has been carrying out border controls at the internal border to Austria as a response to a serious threat to public policy or internal security caused by an uncontrolled influx of exceptionally large numbers of persons. ${ }^{13}$ The provisions of Title II of the Schengen Borders Code, that are operative at the external borders of the Union, apply mutatis mutandis to these border controls under Article 28.

\section{The Application of Art. 20 Paragraph 4 Dublin-III-REG "At the Border"}

According to its plain wording, Article 20, Paragraph 4 of Dublin-III-REG applies as soon as border-crossing checks occur on the border line or in the geographical territory of the "transit" Member State (e.g. Austria). In these situations, the applicant is still undeniably in Austrian territory.

Nothing else can then apply when the border control occurs slightly set back beyond the border and within the territory of the state of destination, such as Germany. According to the Schengen Borders Code, a third-state national has de jure not entered the territory of a Member State if he has been denied entry in the course of border controls and border checks "at" a "border crossing point." ${ }^{14}$

The counterargument is that third-state nationals who apply for international protection at a border crossing point located on the German geographical territory have already exited Austria. The German transit zone itself is already German territory under international law, which is why Article 20, paragraph 4 of the Dublin-III-REG could not be applied. ${ }^{15}$ This argument is not convincing.

Article 15 of the Dublin-III-REG has a special regulation for transit zones, which states that if an application for international protection is lodged in the international transit area of a Member State's airport, that Member State is responsible for examining that application. This provision, tailored to the external borders of the Union, cannot be applied at the internal land borders between Member States. Rather, in those situations, Article 20

13 See Treaty of Lisbon Amending the Treaty on European Union and the Treaty Establishing the European Community, art. 72, Dec. 13, 2007, 2007 O.J. (C 306) 1 [hereinafter Treaty of Lisbon]; see also id. art. 23.

${ }^{14}$ At external Schengen borders that are simultaneously Dublin internal borders - specifically Slovakia/Hungary to Croatia, as well as Hungary and Bulgaria-Art. 13 paragraph 4 of the Schengen Borders Code directly applies. See Schengen Borders Code, supra note 1, art. 13, para. 4. See also id. art. 28, and art. 2, no. 8-10 and 13. On German law, see Aufenthaltsgesetz [AufenthG] [Residence Act], Feb. 25, 2008, BunDESGESETZBLATT [BGBL I] at 162, § 13, para. 2 , sentence 1 , which is in clear contrast to mere border crossing under $\S 13$, para. 2 , sentence 3 .

15 Anna Lübbe, Ist der deutsche Transit österreichisches Staatsgebiet?, VeRFASSUNGSBLOG (Mar. 7, 2016), http://verfassungsblog.de/ist-der-deutsche-transit-oesterreichisches-hoheitsgebiet/ [hereinafter Anna Lübbe]; see Constantin Hruschka, Rückkehr zum Recht an der deutsch-österreichischen Grenze? Zur Zuständigkeit für an der deutschen Grenze Asylanträge, (Mar. http://fluechtlingsforschung.net/ruckkehr-zum-recht-an-der-deutsch-osterreichischen-grenze/. 
paragraph 4 of the Dublin-III-REG applies. If Article 20, Paragraph 4 of the Dublin-III-REG, as expressly proclaimed by the Commission, ${ }^{16}$ is also to apply "at the frontier," the precise geographical locus of the border crossing point cannot be decisive. Otherwise, the intent and purpose of this provision would be misjudged, which is meant to activate the asylumlegal responsibility of the Member State that in turn has permitted the presence of the thirdstate national on its territory. In its statement that Article 20, paragraph 4 of the Dublin-IIIREG also applies "at the frontier," the Commission was well aware that the border check that decides the issuance of an entry permit in fact regularly takes place "at" the border, but "on" the geographical territory of the country of destination. The position advanced here is supported by a legal-teleological interpretation of the notion of "territory": ${ }^{17}$ As a "no man's land" between Germany and Austria does not exist according to international law, an application that is submitted to the German border control before passing a German border crossing points, has to be considered as having still been submitted "on the territory" of Austria. If one were to see this differently, the results would be random. A border crossing point can be located-from a German perspective-upstream. It could be in front of the border, on Austrian territory-which would require Austria's cooperation-exactly on the border line or somewhat set back into the interior. In the first two cases, Article 20, paragraph 4 of the Dublin-III-REG would apply "at the border"; in the third and final case, it would not. In practice, that would mean that whoever manages to set foot on German soil would have to be allowed entry, and whoever does not, would have to stay out. Such an extremely state-territorial interpretation of the European asylum and border regime leads to less plausible differentiations and random results.

In any case, what should be noted, is that the border checks can be organized in such a way that due to an applicant being present in Austrian geographical territory, the applicant can be referred to Austria according to Article 20 IV of the Dublin-III-REG.

Apparently, the Federal Minister of the Interior implicitly assumed the general applicability of this provision because, while simultaneously implementing internal border controls to Austria, on September 13, 2015, he decided "that measures at the border for returning thirdstate nationals seeking protection, are currently not being applied."18

\footnotetext{
${ }^{16}$ See Proposal for a Council Regulation Establishing the Criteria and Mechanisms for Determining the Member State Responsible for Examining an Asylum Application Lodged in One of the Member States by a Third-Country National, COM (2001) 447 final (July 26, 2001).

17 Christian FilzWieser \& Andrea Sprung, Dublin III-Verordnung, Kommentar, art. 20, k. 17 (Berliner Wissenschafts-Verlag 2014) (finding "actually sensible, further teleological interpretation" as hardly compatible with the "precise term 'territory"').

${ }^{18}$ For an answer from the Federal Government, see Response, supra note 4, at 2. See also Asylum Act § 18, para. 2, no. 2 (enabling a swift return to the state that is responsible for the asylum application under immediate consideration of the Dublin-III-REG); see also Asylgesetz [AslyG] [Asylum Act], Sept. 2, 2008, BGBL I at 1798, § 18, para. 2, no. 2; Dublin-III-REG, supra note 6, art. 20, para. 4; Regierungsentwurf [Cabinet Draft], DEUTSCHER BUNDESTAGS: DRUCKSACHE [BT] 16/5065, at 215 (Ger.), with Dublin-III_REG, supra note 6, art. 20, para. 4.
} 


\section{The Legal Consequence of Article 20, Paragraph 4 of the Dublin-III-REG}

If an application for international protection is lodged at the German-Austrian border, Germany is not legally obligated to issue an entry permit. Rather, the state of residencethe "transit" Member State- "shall be informed without delay by the Member State which received the application and shall then, for the purposes of this Regulation, be regarded as the Member State with which the application for international protection was lodged." ${ }^{19}$ The responsibility to start the Dublin Procedure and examine the application thus lies and remains with the state of residence, for example Austria. This legal consequence does not lie at the discretion of the German border agencies.

It also does not lead to any hardships for the applicant that amount to being intolerable or contrary to human rights. The provision does not authorize formless repulsions that in fact are incompatible with the Dublin System. ${ }^{20}$ The applicants are rather "informed in writing of this change in the determining Member State and of the date on which it took place." ${ }^{21}$ By fulfilling this information obligation, applicants are placed in a position of being capable of claiming their EU-given asylum rights with a clearly-identified Member State. Should it become apparent in the course of Austria's responsibility-examination that Germany is instead responsible for the asylum demand of certain applicants-because, for instance, their family members already reside here ${ }^{22}$-then Austria has to conduct a take charge request according to Article 21 of the Dublin-III-REG.

The terrible scenario of a refugee stuck in transit-orbit ${ }^{23}$ could only occur if the Austrian authorities refuse to carry out the asylum procedure which has already been initiated through a successful application lodged with the German border guards. Such a refusal would clearly breach the obligations of Austria under the Dublin-III-REG. Such conduct cannot be implied. ${ }^{24}$

\footnotetext{
${ }^{19}$ Dublin-III-REG, supra note 6, art. 20, para. 4, subpara. 1, sentence 2.

${ }^{20}$ See Sharifi v. Italy, App. No. 16643/09, (Oct. 21, 2014), http://hudoc.echr.coe.int/; HolgER WINKELMANN, GÜNTER ReNnER, JAN BERGMANn \& KLAUS Dienelt, AusläNDERRECHT, § 18 Asylum Procedure Act, para. 23 (10th ed. 2013).

${ }^{21}$ Dublin-III-REG, supra note 6, art. 20, para. 4, subpara. 2.

${ }^{22}$ See id. art. 8-11, 16.

${ }^{23}$ See Anna Lübbe, supra note 14.

${ }^{24}$ Incidentally, all Member States along the "Balkan route" would naturally have to be informed ahead of time of the hitherto absent application of Art. 20 paragraph 4 of the Dublin-III-REG on the basis of Union loyalty. See Treaty of Lisbon art. 4, para. 3. This would bring a definitive end to the policy of "waving through."
} 


\section{Differentiating External and Internal Relations}

Article 20, paragraph 4 of the Dublin-III-REG integrates well into the overall concept of the Dublin System, which differentiates between applications for protection at an external border and applications at an internal border, and between the relationship between the EU and third countries (external border) and the relationship between Member States (internal borders).

The first sentence of Article 3, paragraph 1 of the Dublin-III-REG states that "[M]ember States shall examine any application for international protection by a third-country national or a stateless person who applies on the territory of any one of them, including at the border or in the transit zones." This, however, is a collective promise of the Member States that participate in the Common European Asylum System (CEAS). This promise is laid out in the first sentence of Article 78, paragraph 1 TFEU and elaborated in verbatim recitals of Directives in the secondary asylum acquis:

A common policy on asylum, including a Common European Asylum System, is a constituent part of the European Union's objective of establishing progressively an area of freedom, security and justice open to those who, forced by circumstances, legitimately seek protection in the Union. Such a policy should be governed by the principle of solidarity and fair sharing of responsibility, including its financial implications, between the Member States. ${ }^{25}$

Therefore, it is the EU that is open to all applicants seeking protection. The passage "including at the border" in the first sentence of Article 3, paragraph 1 of Dublin-III-REG signals, in this context, that the requirements of adhering to the principle of non-refoulement of Article 33 of the Geneva Convention is completely complied with; specifically, there will be no return to a state where persecution exists or insufficient protection is provided-which generally can only be considered at external borders. ${ }^{26}$ The

\footnotetext{
25 Directive 2013/32, of the European Parliament and of the Council of 26 June 2013 on Common Procedures for Granting and Withdrawing International Protection (recast), 2013 O.J. (L 180) 60; see Directive 2013/33, of the European Parliament and of the Council of 26 June 2013 Laying Down Standards for the Reception of Applicants for International Protection (Recast), 2013 O.J. (L 180) 96; Directive 2011/95 of the European Parliament and of the Council of 13 Dec 2011 on Standards for the Qualification of Third-Country Nationals or Stateless Persons as Beneficiaries of International Protection, for a Uniform Status for Refugees or for Persons Eligible for Subsidiary Protection, and for the Content of the Protection Granted (recast), 2011 O.J. (L 337) 9.

26 This also explains why Directive 2013/32 of the European Parliament and of the Council of 26 June 2013 on Common Procedures for Granting and Withdrawing International Protection (Recast), 2013 O.J. (L 180) 60, art. 8,
} 
first sentence of Article 3, paragraph 1 of the Dublin-III-REG thereby ultimately only statesyet at least-that every refugee is given the guarantee that his application will be examined by a Member State. ${ }^{27}$ Therefore, at the "external border" of the EU, or in an international transit area of an airport, an applicant may not be relegated to seek protection in the thirdstate from which he has traveled ${ }^{28}-$ unless the repulsion is made to a safe third state (Article 3, paragraph 3 Dublin-III-REG). ${ }^{29}$

The "external" openness of the EU does not answer the question of which Member State is responsible for all those who "legitimately seek protection in the Union?" 30 In the case of reintroducing internal border checks, this could either be the Member State on this or the other side of the internal border. This responsibility needs to be clarified.

The fact that the internal distribution of responsibility is not regulated by the first sentence of paragraph 1 of Article 3 of the Dublin-III-REG ${ }^{31}$ is made clear by the second sentence of that paragraph, which states that an "application shall be examined by a single Member State, which shall be the one which the criteria set out in Chapter III indicate is responsible." ${ }^{\prime 32}$ The preceding "[p]rocess of determining the Member State responsible" for this examination has been regulated separately in the section on the "start of the procedure" in Chapter VI of Article 20. The special rules of Article 20, paragraph 4 of the Dublin-III-REG for applications at internal borders also allow for the previous EU state of residence to be considered the state of the initial application, which prevents the assignment of any subsidiary responsibility to Germany as the "first Member State in which the application for

\footnotetext{
para. 1, encourages Member States along the external border, to already support applications for international protection, if a willingness for such is discernible merely in transit zones.

${ }^{27}$ See The Convention Determining the State Responsible for Examining Applications for Asylum Lodged in One of the Member States of the European Communities - Dublin Convention, Preamble, Aug. 19, 1997, 1997 O.J. (C 254) [hereinafter Dublin Convention]. For a memorandum of the Federal Government on the Dublin Convention, see Regierungsentwurf [Cabinet Draft], DEUTSCHER BUndeSTAGS: DRUCKSACHE [BT] 12/6485 (Ger.) [hereinafter Cabinet Draft].

${ }^{28}$ See Dublin-III-REG, supra note 6, art. 15.

${ }^{29}$ See Directive 2013/32 of the European Parliament and of the Council of 26 June 2013 on Common Procedures for Granting and Withdrawing International Protection (Recast), 2013 O.J. (L 180) 60, art. 33, para. 2 (showing that in this case as well the Member States do not have to examine an application for protection in the case of an arrival from safe third states).

${ }^{30}$ See Anna Lübbe, supra note 15.

${ }^{31}$ Contra Jürgen Bast \& Christoph Möllers, Dem Freistaat zum Gefallen: über Udo Di Fabios Gutachten zur staatsrechtlichen Beurteilung der Flüchtlingskrise, VERFASSUNGSBLOG, http://verfassungsblog.de/dem-freistaat-zumgefallen-ueber-udo-di-fabios-gutachten-zur-staatsrechtlichen-beurteilung-der-fluechtlingskrise/ (last visited Mar. 7, 2016).

${ }^{32}$ Cabinet Draft, supra note 17.
} 
international protection was lodged" under Article 3, paragraph 1, subparagraph 1 of the Dublin-III-REG.

\section{The Discretionary Clause and Entry Permit on Humanitarian Reasons}

\section{The Discretionary Clause of Article 17 I Dublin-III-REG and Its Limits}

If it is the "transit" Member State that is responsible for starting the Dublin Process and examining international applications, German authorities need another legal basis for deciding to examine such applications. In fact, and by way of derogation from Article 3, paragraph 1 of the Dublin-III-REG, Article 17, paragraph 1 of the Dublin-III-REG grants Member States the discretion to "decide to examine an application for international protection lodged with it by a third-country national or a stateless person, even if such examination is not its responsibility under the criteria laid down in this Regulation." By exercising this discretion, this Member State becomes the responsible Member State and assumes the obligations connected to this responsibility. As a consequence, an asylumseeker coming from EU countries and other safe third-countries cannot be denied entry.

Germany has clearly made use of this option in the case of Syrian refugees in the course of 2015. ${ }^{33}$ Nonetheless, since the end of October 2015, the regular Dublin Procedures have applied again. ${ }^{34}$ The German Minister of Justice also declared that the German government relied on the discretionary clause of Article 17, paragraph 1 of the Dublin-III-REG only until November 2015. ${ }^{35}$ Whether the temporary reliance on the discretionary clause conformed to European law shall not be examined here, especially because it has been concluded in the meantime. From a procedural perspective, Article 17 of the Dublin-III-REG decrees obligations to provide information. Nothing is known about whether these obligations have been met. Moreover, it is doubtful whether Article 17, paragraph 1 of the Dublin-III-REG is the proper basis to permit the entry of thousands of unidentified persons. ${ }^{36}$ In any case, making use of the discretionary clause is an option of Member States, not an obligation. ${ }^{37}$ It

\footnotetext{
${ }^{33}$ This decision, made on Aug. 21, 2015, was communicated via a tweet by the BAMF. See BAMF (@BAMF_Dialog), TWITTER (Aug. 25, 2014, 4:30 AM) https://twitter.com/bamf_dialog/status/636138495468285952.

34 See Deutschland wendet Dublin-Verfahren wieder für Syrer an, DeUTSCHE Welle (Nov. 10, 2015), http://www.dw.com/de/deutschland-wendet-dublin-verfahren-wieder-f\%C3\%BCr-syrer-an/a-18841749 (last visited on Mar. 7, 2016) (showing that the BAMF, since Oct. 21, 2015 no longer "generally makes use of its right to act sovereignly on its own", but rather "in a continuous process," checks whether the responsibility exists for a different Member State as per Dublin-III-REG).

35 Heiko Maas, Wer das Recht wirklich schwächt, Frankfurter Allgemeine Zeitung (Jan. 20, 2016), http://www.faz.net/aktuell/politik/fluechtlingskrise/gastbeitrag-von-justizminister-heiko-maas-14041595.html.

${ }^{36} \mathrm{Cf}$. Research Section of the German Bundestag, elaboration on Nov. 26, 2105, entry of asylum seekers from safe third countries, Az.: WD 3 - 3000 - 299/15, p. 7 under 2.4.

${ }^{37}$ See Case C-4/11, Germany v. Puid, paras. 29, 33 (Nov. 14, 2013), http://curia.europa.eu/.
} 
is an exception to the rules which, from the perspective of EU law, in no way justifies the provision of entry permits to an unlimited amount of people or for an unlimited amount of time. ${ }^{38}$ In considering the CEAS as a whole, the CJEU too has clearly rejected a blanket suspension of the Dublin System in the name of fundamental rights. ${ }^{39}$

\section{Entry Permits on Humanitarian Grounds, Section 18, Paragraph 4 No. 2 German Asylum Act}

Now that the discretionary clause under Dublin is no longer in discussion, entry permits for third-country nationals seeking national and/or international protection at the GermanAustrian border can, at most, only be supported by an order of the Federal Ministry of the Interior under Section 18, paragraph 4 of the German Asylum Act "on humanitarian grounds, for reasons of international law or in the political interests of the Federal Republic of Germany." In fact, such an order was apparently made simultaneously with the introduction of border checks at the internal border to Austria. On September 13, 2015, the Federal Ministry of the Interior decided that "[m]easures for repulsion at the border regarding thirdcountry nationals seeking protection . . . are currently not being applied." ${ }^{40}$ Irrespective of how narrowly or broadly one interprets this provision, its application must respect the primacy of EU law. And EU law, as explained, provides for a reference procedure if an application for international protection is lodged at an internal border between Member States. This rule of Article 20, paragraph 4 of the Dublin-III-REG is not at the discretion of the German authorities. ${ }^{41}$

\footnotetext{
38 FILZWIESER, supra note 17, art. 17 (Berliner Wissenschafts-Verlag 2014). The same applies to entry permits according to Art. 13, paragraph 1, first sentence in conjunction with Art. 5, paragraph 4, lit. c of the Schengen Borders Code on "humanitarian grounds," as long as one sees the rule of exception as applicable the permitting reasons are drawn from the reasons for protection of the laws of asylum. Schengen Borders Code, supra note 1 , art. 13, para. 1 , sentence 1 , art. 4 , para. 4 , lit. c.

${ }^{39}$ See Joined Cases C-411/10 \& C-493/10, N. S. vs. Sec'y of State for the Home Dep't, para. 83 (Dec. 21, 2011), http://curia.europa.eu/.

${ }^{40}$ Response, supra note 4 , at 2.

${ }^{41}$ The Federal Government acted inconsistently on this when it no longer invoked the right to sole sovereign action under Art. 17, paragraph 1 of Dublin-III-REG, yet at the same time a ministers' order on a national legal base was meant to yield the same result. See Dublin-III-REG, supra note 6, art. 17, para. 1.
} 


\section{E. Conclusion}

As a result, entry shall be refused to third-country nationals or stateless persons who lodge an application at reintroduced control points at internal borders between Member States, in particular at the Austrian-German land border. ${ }^{42}$

The consistent application of Article 20, paragraph 4 of the Dublin-III-REG at all internal borders where border controls are reintroduced due to exceptionally large numbers of irregular secondary movements within the Schengen area is a first step to restoring both the Dublin and Schengen Systems-no more, yet no less either. To tackle the migration crisis beyond that, more comprehensive support-and assistance-measures in favor of the Member States of first entry into the EU (in particular Greece and Italy) and the countries of origin are certainly needed.

${ }^{42}$ See Schengen Borders Code, supra note 1, art. 13, para. 1; see also Aufenthaltsgesetz [AufenthG] [Residence Act], Feb. 25, 2008, BGBL. I at 162, § 14, para. 1, § 15, para. 1; Asylgesetz [AslyG] [Asylum Act], Sept. 2, 2008, BGBL I at 1798 , § 18 , para. 2 , no. 1. 
